\title{
Stunting and Its Associated Factors Among Children Age 6-59 Months at Debre Tabor Town, Northwest Ethiopia, 2019; a Community Based Cross-sectional Study
}

Bisrat Dessie Getu ( $\square$ edombsr10@gmail.com )

Debre Tabor Health science college

Kendalem Asmare Atalell

University of Gondar

Destaye Guadie Kassie

University of Gondar

Kefyalew Amogne Azanaw

Debre Tabor Health Science College

Nigusie Selomon Tibebu

Debre Tabor University

\section{Research}

Keywords: Children, Stunting, Debre Tabor town, Ethiopia

Posted Date: February 9th, 2022

DOI: https://doi.org/10.21203/rs.3.rs-1055501/v1

License: (c) (i) This work is licensed under a Creative Commons Attribution 4.0 International License.

Read Full License 


\section{Abstract}

Introduction: Globally in U5 year children, greater than half of all deaths are attributable to under-nutrition. Stunting is one of the major under-nutrition problems in children, especially in developing countries like Ethiopia. Therefore, this study was aimed to assess the prevalence of stunting and its associated factors among children age 6-59 months at Debre tabor Town, Northwest Ethiopia, 2019.

Methods: Community-based cross-sectional study design was conducted among children age 6-59 months at Debre Tabor town, from February to March 2019. Data were collected using a pretested, semistructured an interviewer-administered questionnaire adapted from WHO stepwise surveillance (WHO STEPS). A systematic random sampling technique was used to engage 620 parent-child pairs. Data was entered into Epi-info version 7 and exported to SPSS version 22 for analysis. Height for age $Z$ score was computed using WHO Anthro plus software. Both the bivariable and a multivariable logistic regression analyses were computed and adjusted odds ratio (AOR) at $p$-value $<0.05$ was used to determine the statistically significant association between factors and the outcome variable.

Result: The prevalence of stunting in this study was $46 \%$ (95\% Cl: $41.9 \%-50.3 \%)$. Age of the child [AOR=1.98, 95\%Cl: $(1.08,3.67)]$, occupation of the mother [AOR=2.13, 95\% Cl: $(1.16,3.92)]$, educational status of the father [AOR=2.88, 95\% Cl: $(1.45,5.70)]$ and occupation of the father $[A O R=5.05,95 \% \mathrm{Cl}$ : $(2.46,10.36)]$ were variables significantly associated with stunting.

Conclusion: The prevalence of stunting was found to be high among children age 6-59 months in the study area as compared to the national average. The age of the child, occupation of the mother, the educational status of the father, and occupation of the father were factors associated with stunting? Therefore, attention should be targeted to improve the occupational and educational status of the parents.

\section{Introduction}

Globally, in under five children greater than half of all deaths are attributable to under-nutrition [1]. Besides, stunting is one of the most common markers of under-nutrition, which is a linear growth failure or inability to gain a potential height for a particular age [2,3].

According to UNICEF, and World Bank 2019 reports, more than one in five children under the age of 5 years had stunted growth [1]. Even though stunting decreases globally from in the last decades, it is increased in alarming rates in Africa[2, 4]. Furthermore, in Ethiopia, according to the Ethiopian Demographic health survey (EDHS) 2016, stunting was 38\% [5].

According to WHO conceptual frame work on childhood stunting, the household and family incomes, breastfeeding techniques of children, infection, and complementary feeding practices were some of the contributing factors of stunting [6]. The global review of stunting in low- and middle-income countries also identified that growth restriction in-utero and lack of access to sanitation as the main driving factors 
for stunting [7]. Consequently, stunting in children results in susceptibility to infectious disease, diminish intellectual ability, and poor school performance [4, 8-10]. Moreover, stunted children may never regain their height loss again in their lifetime [11].

Despite the global burden of stunting, it is not often recognize in the communities, especially in low and middle-income countries like Ethiopia [12,13]. Even though, stunting in Ethiopia, reduced from $58 \%$ according to Ethiopian Demographic Health Survey (EDHS) 2000 [14], to 38\% EDHS 2016 [5], in under-five children. However, this progress is not sufficient to meet the global target [15]. The risk factors of stunting in a different setting is different for under-five children [16]. Thus, to address this gap, this study was aimed to assess the prevalence of stunting and its associated factors among children age 6-59 months at Debre tabor Town, Northwest Ethiopia, 2019.

\section{Methods}

\section{Study design and setting}

Community-based cross-sectional study design was conducted to assess stunting among children age 659 months at Debre tabor town, Northwest Ethiopia, from February to March 2019.

The study was conducted at Debre tabor town, which is found in the Northwest part of Ethiopia. The general population of Debre tabor town is estimated to be 84,382 of this 10,868 were children, age 6-59 months [17].

\section{Study participants and sampling}

All children age 6-59 months living at Debre Tabor town were eligible for this study. The town has six kebeles; each kebele was considered as a cluster. Then, three clusters (50\% of the cluster) were selected randomly by the lottery method. Households with children age 6-59 months in the three clusters were obtained from health extension workers in each cluster. Using health extension workers registrations as a frame of reference studied households were selected by systematic random sampling technique. For more than one eligible child in one household, the lottery method was used.

\section{Dependent Variable}

- Stunting (below -2 SD) children age from 6-59 months

\section{Independent Variables}

- Socio- Demographic, and Economic Characteristics

- Maternal Characteristics

- Childs' Characteristics

- Environmental Characteristics 
- Stunting: A child is defined as stunted if the height-for-age Z-score is found to be below -2 SD of the median of the WHO standard curve.

\section{Data collection tools and procedures}

Data were collected by using a pretested, semi-structured interviewer-administered questionnaire, which is adopted from WHO stepwise surveillance (WHO STEPS) for child malnutrition. The questionnaire comprised of socio-demographic, economic, environmental conditions, and child health-related characteristics.

The data were collected by five BSc nurses. Mothers or caregivers were interviewed whereas; anthropometry measurements were taken from children. The height of infants aged six to 23 months was measured in a recumbent position to the nearest $0.1 \mathrm{~cm}$, using a board with an upright wooden base and movable headpieces. Children aged 24 to 59 months were measured in a standing up position to the nearest $0.1 \mathrm{~cm}$. additionally, child weight was measured by an electronic digital weight scale to the nearest $0.1 \mathrm{~kg}$. The calibers of the measurements were checked before and after the measurement of the individual child.

\section{Data processing and analysis}

Data were entered into EPI-info version 7 and then exported to SPSS version 12 for analysis. WHO AnthroPlus software was used to convert nutritional data into $Z$ scores of the indices HAZ using the WHO standard. In addition, principal component analysis (PCA) was used to compute family wealth status.

Both bivariate and multivariable binary logistic regression models were computed to identify factors associated with stunting among children age 6-59 months. A bivariate binary logistic regression model was first computed, and variables less than 0.2 in the bivariate analysis were entered into the multivariable logistic regression model. In the final multivariable analysis, variables having a p-value less than 0.05 at $95 \% \mathrm{Cl}$ were considered as significantly associated with stunting.

\section{Result}

\section{Socio-demographic and economic characteristics of the study participants}

A total of 620 children age 6-59 months were included in the analysis. The majority (91.0\%) of the mothers/caregivers were married and (90.6\%) Orthodox Christian in Religion. Nearly three fourth $(72.4 \%)$ of the fathers had high school and above educational status (Table1). 
Table 1

Socio-demographic characteristics of children age 6-59 months at Debre tabor town, Northwest Ethiopia, $2019(\mathrm{n}=620)$.

\begin{tabular}{|c|c|c|c|}
\hline \multicolumn{2}{|l|}{ Characteristics } & \multirow{2}{*}{$\begin{array}{l}\text { Frequency } \\
564\end{array}$} & \multirow{2}{*}{$\begin{array}{l}\text { Percentage } \\
91.0\end{array}$} \\
\hline Marital status & Married & & \\
\hline & Single & 56 & 9.0 \\
\hline \multirow[t]{3}{*}{ Religion } & Orthodox & 562 & 90.6 \\
\hline & Muslim & 44 & 7.1 \\
\hline & Protestant & 14 & 2.3 \\
\hline \multirow[t]{3}{*}{ Ethnicity } & Amhara & 601 & 96.9 \\
\hline & Oromo & 17 & 2.7 \\
\hline & Gurage & 2 & 0.3 \\
\hline \multirow{3}{*}{$\begin{array}{l}\text { The educational status of } \\
\text { the mother }\end{array}$} & No formal education & 127 & 20.5 \\
\hline & Primary education & 143 & 23.1 \\
\hline & Highschooland above & 350 & 56.5 \\
\hline \multirow{3}{*}{$\begin{array}{l}\text { The educational status of } \\
\text { the father }\end{array}$} & No formal education & 97 & 15.6 \\
\hline & Primary education & 74 & 11.9 \\
\hline & Highschooland above & 449 & 72.4 \\
\hline \multirow[t]{5}{*}{ Occupation of mother } & Housewife & 284 & 46.5 \\
\hline & Daily laborer & 41 & 6.7 \\
\hline & Private organization & 21 & 3.4 \\
\hline & Merchant & 95 & 15.5 \\
\hline & Government employee & 170 & 27.8 \\
\hline \multirow[t]{4}{*}{ Occupation of father } & Daily laborer & 95 & 15.5 \\
\hline & Private organization & 96 & 15.7 \\
\hline & Merchant & 158 & 25.8 \\
\hline & Government employee & 264 & 43.1 \\
\hline \multirow[t]{2}{*}{ Family size } & Less than 5 & 503 & 81.1 \\
\hline & Greater than or equal to 5 & 117 & 18.9 \\
\hline Totalnumberof & $\leq 2$ & 466 & 75.2 \\
\hline
\end{tabular}




\begin{tabular}{|llll|}
\hline Chder-five chaiddren & & Frequency & Percentage \\
\hline \multirow{3}{*}{ Total number of children } & $>2$ & 154 & 24.8 \\
\cline { 2 - 4 } & Less than four & 576 & 92.9 \\
\cline { 2 - 4 } Wealth status of the family & Greater than or equal to four & 44 & 7.1 \\
\cline { 2 - 4 } & Poor & 204 & 32.9 \\
\cline { 2 - 4 } & Medium & 208 & 33.5 \\
\cline { 2 - 4 } & Rich & 208 & 33.5 \\
\hline
\end{tabular}

\section{Child characteristics}

The mean age of the study participants was 27 ( $\pm 14 S D)$ months. Slightly higher than half $(52.3 \%)$ of the children were males. Six hundred twelve (98.7\%) of children were ever immunized (Table 2). 
Table 2

Child characteristics of children age 6-59 months at Debre tabor town, Northwest Ethiopia, 2019( $n=620)$.

\begin{tabular}{|c|c|c|c|}
\hline \multicolumn{2}{|l|}{ Characteristics } & \multirow{2}{*}{$\begin{array}{l}\text { Frequency } \\
324\end{array}$} & \multirow{2}{*}{$\begin{array}{l}\text { Percentage } \\
52.3\end{array}$} \\
\hline Sex of the child & Male & & \\
\hline & Female & 296 & 47.7 \\
\hline Age of the child & 6-11 months & 110 & 17.7 \\
\hline \multirow[t]{4}{*}{$27 \pm 14$ SD } & $12-23$ months & 146 & 23.5 \\
\hline & 24-35months & 159 & 25.6 \\
\hline & 36- 47 months & 138 & 22.3 \\
\hline & 48-59 moths & 67 & 10.8 \\
\hline \multirow[t]{2}{*}{ Ever breastfeeding } & Yes & 615 & 99.0 \\
\hline & No & 5 & 1.1 \\
\hline \multirow[t]{2}{*}{ Ever immunized } & Yes & 612 & 98.7 \\
\hline & No & 8 & 1.3 \\
\hline \multirow[t]{2}{*}{ Breastfeeding initiations time } & Before 1 hour & 500 & 81.0 \\
\hline & Greater than 1 hours & 120 & 19.0 \\
\hline \multirow[t]{2}{*}{ Pre-lacteal feeding use } & Yes & 47 & 7.6 \\
\hline & No & 573 & 92.4 \\
\hline \multirow[t]{4}{*}{ Types of pre-lacteal feeding } & Water & 16 & 2.6 \\
\hline & Butter & 14 & 2.3 \\
\hline & Milk & 15 & 2.4 \\
\hline & Others (Habish, meqamesha) & 2 & 0.3 \\
\hline
\end{tabular}

\section{Maternal characteristics}

Five hundred ninety-one (95.3\%) of the mothers/caregivers utilize family planning methods. Nearly three fourth $(72.6 \%)$ of the mothers were utilized Depo-Provera (Tabe3). 
Table 3

Maternal characteristics of children age 6-59 months at Debre tabor Town, Northwest Ethiopia $2019(\mathrm{n}=620)$.

\begin{tabular}{|llll|}
\hline Characteristics & & Frequency & Percentage \\
\hline Age of the mothers/caregivers & $<25$ & 69 & 11.1 \\
\cline { 2 - 4 } & $25-30$ & 303 & 48.9 \\
\cline { 2 - 4 } Family planning utilizations & $>30$ & 248 & 40.0 \\
\cline { 2 - 4 } Pills & Yes & 591 & 95.3 \\
\cline { 2 - 4 } & No & 29 & 4.7 \\
\hline Depo-Provera & Yes & 119 & 19.2 \\
\cline { 2 - 4 } & No & 501 & 80.8 \\
\hline Norplant & Yes & 450 & 72.6 \\
\cline { 2 - 4 } & No & 170 & 27.4 \\
\hline Is the pregnancy planned & Yes & 104 & 16.8 \\
\cline { 2 - 4 } & No & 516 & 83.2 \\
\cline { 2 - 4 } & Yes & 548 & 88.4 \\
\cline { 2 - 4 } & No & 72 & 11.6 \\
\hline
\end{tabular}

\section{Environmental characteristics}

Five hundred and fifty-six (89.7\%) of the respondents use private tap water as their main water source. The majority of the respondents 615 (99.2\%) have latrine.

Eighty-five (13.7\%) of the respondents don't have a separate kitchen for their food preparations (Table 4). 
Table 4

Environmental characteristics of children age 6-59 months at Debre tabor town, Northwest Ethiopia, $2019(n=620)$.

\begin{tabular}{|c|c|c|c|}
\hline Characteristics & & Frequency & Percentage \\
\hline Source of drinking water & & & \\
\hline Private well & Yes & 129 & 20.8 \\
\hline & No & 491 & 79.2 \\
\hline Private tap & Yes & 556 & 89.7 \\
\hline & No & 64 & 10.3 \\
\hline Public tap & Yes & 26 & 4.2 \\
\hline & No & 594 & 95.8 \\
\hline Spring water & Yes & 92 & 14.8 \\
\hline & No & 528 & 85.2 \\
\hline Amount of water used in the household & $<50$ liters & 332 & 53.5 \\
\hline & $50-75$ liters & 282 & 45.5 \\
\hline & >75litrs & 6 & 1.0 \\
\hline Water treatment utilizations & Yes & 98 & 15.8 \\
\hline & No & 522 & 84.2 \\
\hline Latrine & Yes & 615 & 99.2 \\
\hline & No & 5 & 0.8 \\
\hline Type of latrine & Private pit/wooden slab & 503 & 81.2 \\
\hline & Privateslab/cement Slab & 77 & 12.5 \\
\hline & Sharedlatrine/wooden Slab & 7 & 1.2 \\
\hline & Shared VIP latrine & 13 & 2.1 \\
\hline & Others like an open field & 20 & 3.0 \\
\hline Waste disposal & Open field & 190 & 30.6 \\
\hline & Private pit & 49 & 7.9 \\
\hline & Common pit & 21 & 3.4 \\
\hline & Composting & 10 & 1.6 \\
\hline & Burning & 302 & 48.7 \\
\hline
\end{tabular}




\begin{tabular}{|llll|}
\hline Characteristics & & Frequency & Percentage \\
\hline \multirow{3}{*}{ Kitchen } & Other & 48 & 7.7 \\
& Yes & 535 & 86.3 \\
\cline { 2 - 4 } & No & 85 & 13.7 \\
\hline
\end{tabular}

\section{Prevalence of stunting among children age 6-59 months}

The overall prevalence of stunting among children age 6-59 months at Debre tabor town was $46 \%$ at $95 \%$ $\mathrm{Cl}$ (41.9-50.3) (Figure (1).

\section{Factors associated with stunting among children age 6-59 months}

In the bivariate logistic regression analysis, age of the child, educational level of the mother, educational level of the father, occupation of the father, occupation of the mother, total number of children, family size, family planning use, and family wealthy status were significantly associated with stunting. However, in the multivariable logistic regression analysis; the age of the child, the educational status of the father, occupation of the father, and occupation of the mother remained significantly associated with stunting.

The odds of having stunting among children with the age group of 12-23 months were nearly 2 times higher as compared to children with age groups of $6-11$ months age $(A O R=1.98 ; 95 \% \mathrm{Cl}: 1.08,3.67)$. The odds of having stunting among children who had a daily laborer fathers were 5 (AOR= $5.03 ; 95 \% \mathrm{Cl}$ : $2.45,10.36)$ times and children with father who works in private organizations were $2.4(\mathrm{AOR}=2.36 ; 95 \% \mathrm{Cl}$ : $1.29,4.33$ ) times higher as compared with children whose fathers were governmental employees respectively. Similarly, the odds of having stunting among children who had a father with no formal education were nearly $3(\mathrm{AOR}=2.88 ; 95 \% \mathrm{Cl}: 1.45,5.70)$ times and children with fathers who attend primary school were $2(\mathrm{AOR}=1.98 ; 95 \% \mathrm{Cl}: 1.03,3.79)$ times higher as compared to children with fathers who attended high school and above educational level respectively. The odds of having stunting among children who had housewife mothers were 2 times higher than children of their mothers who were a governmental employee (AOR=2.13; 95\% Cl: 1.16, 3.92) (Table 5). 
Table 5

Factors associated with stunting among children age 6-59 months at Debre tabor Town Northwest, Ethiopia, 2019 ( $\mathrm{n}=620)$.

\begin{tabular}{|c|c|c|c|c|c|}
\hline \multirow[t]{2}{*}{ Variable } & & \multicolumn{4}{|c|}{ Stunted } \\
\hline & & Yes & No & COR at $95 \% \mathrm{Cl}$ & AOR at $95 \% \mathrm{Cl}$ \\
\hline \multirow[t]{5}{*}{ Age } & $6-11$ months & 35 & 75 & 1 & 1 \\
\hline & $12-23$ months & 70 & 76 & $1.97(1.18,3.31)$ & $1.98(1.08,3.67)^{*}$ \\
\hline & 24-35 months & 73 & 86 & $1.81(1.09,3.02)$ & $1.54(0.84,2.82)$ \\
\hline & 35-47 months & 69 & 69 & $2.14(1.27,3.61)$ & $1.45(0.78,2.71)$ \\
\hline & $48-59$ months & 38 & 29 & $2.81(1.49,5.26)$ & $1.45(0.68,3.10)$ \\
\hline \multirow[t]{3}{*}{ Maternal education } & $\begin{array}{l}\text { No formal } \\
\text { education }\end{array}$ & 85 & 42 & $4.25(2.76,6.54)$ & $0.89(0.46,1.73)$ \\
\hline & Primary education & 87 & 56 & $3.26(2.18,4.88)$ & $1.22(0.73,2.06)$ \\
\hline & $\begin{array}{l}\text { High school and } \\
\text { above }\end{array}$ & 113 & 237 & 1 & 1 \\
\hline \multirow[t]{3}{*}{$\begin{array}{l}\text { Educational status of } \\
\text { the father }\end{array}$} & $\begin{array}{l}\text { No formal } \\
\text { education }\end{array}$ & 71 & 26 & $4.84(2.97,7.89)$ & $2.88(1.45,5.70)^{\star \star}$ \\
\hline & Primary education & 52 & 22 & $4.19(2.45,7.15)$ & $1.98(1.03,3.79)^{*}$ \\
\hline & $\begin{array}{l}\text { High school and } \\
\text { above }\end{array}$ & 162 & 287 & 1 & 1 \\
\hline \multirow{5}{*}{$\begin{array}{l}\text { Occupation of the } \\
\text { mothers }\end{array}$} & Housewife & 169 & 115 & $5.88(3.77,9.17)$ & $2.13(1.16,3.92) *$ \\
\hline & Daily laborer & 28 & 13 & $8.62(4.04,18.38)$ & $1.47(0.57,3.81)$ \\
\hline & $\begin{array}{l}\text { Private } \\
\text { organizations }\end{array}$ & 6 & 15 & $1.60(0.58,4.43)$ & $0.65(0.19,2.10)$ \\
\hline & Merchant & 43 & 52 & $3.31(1.91,5.74)$ & $1.3(0.68,2.67)$ \\
\hline & Gov't employee & 34 & 136 & 1 & 1 \\
\hline \multirow[t]{4}{*}{ Father occupation } & Daily laborer & 76 & 19 & $13.03(7.31,23.2)$ & $5.05(2.46,10.36)^{*}$ \\
\hline & $\begin{array}{l}\text { Private } \\
\text { organization }\end{array}$ & 56 & 40 & $4.56(2.78,7.49)$ & $2.36(1.29,4.33)^{\star \star}$ \\
\hline & Merchant & 86 & 72 & $3.89(2.55,5.94)$ & $1.71(0.99,2.96)$ \\
\hline & Gov't employee & 62 & 202 & 1 & 1 \\
\hline Total number of family & Less than 5 & 214 & 289 & 1 & 1 \\
\hline
\end{tabular}




\begin{tabular}{|c|c|c|c|c|c|}
\hline & $\begin{array}{l}\text { Greater than or } \\
\text { equal to } 5\end{array}$ & 71 & 46 & $2.08(1.38,3.14)$ & $0.57(0.32,1.01)$ \\
\hline \multirow{2}{*}{$\begin{array}{l}\text { Total number of } \\
\text { children }\end{array}$} & Less than four & 258 & 318 & 1 & 1 \\
\hline & $\begin{array}{l}\text { Greater than or } \\
\text { equal to four }\end{array}$ & 27 & 17 & $1.96(1.04,3.67)$ & $0.65(0.27,1.58)$ \\
\hline \multirow{2}{*}{$\begin{array}{l}\text { Total number of under- } \\
\text { five children }\end{array}$} & $\leq 2$ & 206 & 260 & 1 & 1 \\
\hline & $>2$ & 79 & 75 & $0.75(0.52,1.04)$ & $1.13(0.72,1.78)$ \\
\hline \multirow{2}{*}{$\begin{array}{l}\text { Current family } \\
\text { planning use }\end{array}$} & Yes & 202 & 268 & 1 & 1 \\
\hline & No & 83 & 67 & $1.64(1.34,2.4)$ & $1.52(0.95,2.42)$ \\
\hline \multirow[t]{3}{*}{ Family wealth } & Poor & 125 & 79 & $3.05(2.04,4.56)$ & $1.38(0.84,2.26)$ \\
\hline & Medium & 89 & 119 & $1.44(0.97,2.15)$ & $1.11(0.70,1.77)$ \\
\hline & Rich & 71 & 137 & 1 & 1 \\
\hline
\end{tabular}

\section{Discussion}

Stunting is a major public health problem globally. Therefore, the aim of this study was to determine the prevalence of stunting and its associated factors among children age 6-59 months in Debre Tabor town, Northwest Ethiopia.

The overall prevalence of stunting in this study was $46 \%(95 \% \mathrm{Cl} ; 41.9,50.3)$, which is in line with a crosssectional study conducted in Labella Town, Ethiopia 47.3\% [18],Wukro town, Tigray region, Ethiopia 49.2\% [19], Arba Minch Health and Demographic Surveillance Site (HDSS), Ethiopia 47.9\% [20], Pastoral Communities of Afar Regional State, Ethiopia 43.1\%[21], Amhara regional state, Ethiopia 46.3\% [22] and Bule Hora, Ethiopia 47.6\% [23].

However, the finding in this study is higher than the national average reported by EDHS 2016 38\% [5] and other studies conducted at West Gojjam, Ethiopia 24.9\% [24], Aykel town, Northwest Ethiopia 28.4\% [25], SodoZuria District, South Ethiopia 24.9\% [26], Evidence from 2016 Demographic and Health Survey, Ethiopia 38.3\% [27], Bishoftu Town, Oromia Region, Ethiopia 16.1\% [28], Damot Gale district, Southern Ethiopia $41.7 \%$ [29].

This might be due to dietary diversity differences in different areas of Ethiopia. Ethiopia is a multicultural country, which had different child feeding cultures [30,31]

The result in our study is also higher than study conducted in Zambia 40\% [32], Nigeria 38.7\% [33], Southwestern Nigeria $18.6 \%$ [8], Thailand $28.8 \%$ [34], and china $8.4 \%$ [35]. This might be directly related to the difference in the economic status of the countries. 
The underline cause of stunting in children is poverty and lack of educations. Therefore, children lived-in low-income countries like Ethiopia lead to the inadequacy of foods, there is also a problem with the preparations of clean and diversified foods, which directly may cause stunting [36].

On the other hand, the prevalence of stunting in this study was lower than the study done in Belesa, Ethiopia 57.7\% [37], and Kayin State, Myanmar 59.4\% [36]. The higher result observed in Belesa might be due to the fact that the Belesa district is mostly affected by drought, and the study was conducted among rural households $[38,39]$.

The odds of having stunting among children with the age group of 12-23 months were nearly 2 times higher as compared to children with age groups of $6-11$ months age (AOR=1.98; 95\%Cl: 1.08,3.67), which is supported by a study conducted in Labella Town, Ethiopia [18], Damot Gale district, southern Ethiopia 41.7\% [29], SodoZuria District, South Ethiopia 24.9\% [26] and Zambia [32].

This is due to the fact that, in most studies, breastfeeding is universal in Ethiopia, and mostly it continues up to 1 year of age. As we all now breastfeeding greatly reduces the occurrence of stunting. Therefore, after one year of age when most children cease breastfeeding, they might be exposed to stunting.

The other possible explanation might be, in most cases, children are exposed to family food at the age of one to two years. This might again expose the child to stunting [32]. Researchers suggested that children accumulate growth delay during the first 2 years of life with stunting peaking around 2 and 3 years after which they stabilize [40].

The odds of having stunting among children who had a daily laborer father were $5(A O R=5.03 ; 95 \% \mathrm{Cl}$ : $2.45,10.36)$ times and children with a father who works in private organizations were 2.4 (AOR=2.36; $95 \% \mathrm{Cl}: 1.29,4.33)$ times higher as compared with children whose fathers were governmental employees respectively. This might be related to the family income and feeding status of the children, children with government employee fathers would have better income as compared to their counterparts.

The odds of having stunting among children who had a father with no formal education were nearly 3 ( $A O R=2.88 ; 95 \% \mathrm{Cl}:(1.45-5.70)$ times and children with fathers who attend primary school were 2 $(A O R=1.98 ; 95 \% \mathrm{Cl}:(1.03-3.79)$ times higher as compared to children with fathers who attended high school and above educational level respectively.

This is supported by a study conducted at West Gojjam, Ethiopia 24.9\% [24].

The possible reason might be educated fathers had better awareness regarding the kinds and amounts of food appropriate for their children. As the level of education increase, the knowledge of fathers towards child feeding practices, common childhood disorders, child nutritional problems will increase, therefore, stunting will be decreased.

The odds of having stunting among children who had housewife mothers were 2 times higher than children of their mothers who were a governmental employee (AOR=2.13; 95\% Cl: 1.16, 3.92). This might 
be due to related to the income and educational level of the mothers. If the mothers were employed, they should have formal education which implies they will have better awareness regarding child feeding practice. On the other hand, if the mothers were employed, they will have a good income as compared to housewife mothers.

\section{Limitation of the study}

Even though we tried to minimize, there might be a sort of recall bias. Since the study is on an interview base. Furthermore, the study is cross-sectional it does not show a cause-effect relationship between outcome and associated factors

\section{Conclusion}

The prevalence of stunting was found to be higher among children age 6-59 months in Debre tabor town as compared to the national average. The age of the child, the educational status of the father, occupation of the father, and occupation of the mother were variables significantly associated with stunting in this study. Therefore, attention should be targeted to improve the occupational status and the educational levels of the parents.

\section{Declarations}

\section{Ethical Approval and Consent to Participate}

Ethical clearance was obtained from the school of the nursing ethical review committee on behalf of the University of Gondar review board. The verbal informed consent was acceptable and approved by Ethical review board on the behalf of University of Gondar. A permission letter was obtained from the Debre Tabor town department of health. Participants were informed about voluntarism and that they can withdraw at any time of the study if they want not respond. For those who were a volunteer to participate, verbal informed consent was obtained from the mother/caregivers/ for the children involved in this study. At the end of the interview, participants were informed about stunting and associated potential effects.

\section{Competing Interest}

The authors report no conflicts of interest in this work.

\section{Authors' contribution}

$\mathrm{BD}$ and KA wrote the proposal, participated in data collections, analyzed the data, and draft the paper. DG, MC, DA, KA and NS approves the proposal with some revisions, participated in data collections and analysis. All authors were participated in the preparation of the manuscript and approve the final manuscript.

\section{Consent for publication}


All authors were taken consent to participate in a study and having their data published in a journal article. Authors were give verbal consent to publish their data prior to submitting their paper to a journal.

\section{Acknowledgments}

The authors would like to thank the University of Gondar for financial support that made this study possible. They would also like to thank the data collectors for their tolerance and collaboration during the work.

\section{Funding statement}

This research didn't receive any grant from any funding agency in the public, commercial, or not-for-profit sectors.

\section{Data availability statement}

Data will be available upon request from the corresponding author.

\section{References}

1. UNICEF. Malnutrition prevalence remains alarming: stunting is declining too slowly while wasting still impacts the lives of far too many young children. 2020.

2. Demissie S, Worku AJSJPH. Magnitude and factors associated with malnutrition in children 6-59 months of age in the pastoral community of Dollo Ado district, Somali region, Ethiopia. 2013;1(4):175-83.

3. Reinhardt K, Fanzo J. Addressing chronic malnutrition through multi-sectoral, sustainable approaches: a review of the causes and consequences. Frontiers in nutrition. 2014;1:13.

4. WonDiMAgegn ZTJCRiN, Journal FS. Magnitude and determinants of stunting among children in Africa: a systematic review. 2014;2(2):88-93.

5. [Ethiopia] CSA. Ethiopia Demographic and Health Survey (EDHS); 20162016.

6. Stewart C, lannotti L, Dewey K, Michaelsen K, Onyango A. WHO conceptual framework on Childhood Stunting: Context, Causes, and Consequences. Geneva: World Health Organization. 2013.

7. Danaei G, Andrews KG, Sudfeld CR, Fink G, McCoy DC, Peet E, et al. Risk Factors for Childhood Stunting in 137 Developing Countries: A Comparative Risk Assessment Analysis at Global, Regional, and Country Levels. PLoS Med. 2016;13(11):e1002164-e.

8. Olodu MD, Adeyemi AG, Olowookere SA, Esimai OA. Nutritional status of under-five children born to teenage mothers in an urban setting, south-western Nigeria. BMC Research Notes. 2019;12(1):116.

9. Asmare B, Taddele M, Berihun S, Wagnew F. Nutritional status and correlation with academic performance among primary school children, northwest Ethiopia. BMC research notes. 2018;11(1):805. 
10. Seyoum D, Tsegaye R, Tesfaye A. Undernutrition as a predictor of poor academic performance; the case of Nekemte primary school students, Western Ethiopia. BMC research notes. 2019;12(1):727.

11. Caulfield LE, Richard SA, Rivera JA, Musgrove P, Black RE. Stunting, wasting, and micronutrient deficiency disorders. Disease Control Priorities in Developing Countries 2nd edition: The International Bank for Reconstruction and Development/The World Bank; 2006.

12. De Onis M, Branca F. Childhood stunting: a global perspective. Maternal \& child nutrition. 2016;12:1226.

13. Bloss E, Wainaina F, Bailey RCJJotp. Prevalence and predictors of underweight, stunting and wasting among children aged 5 and under in western Kenya. 2004;50(5):260-70.

14. [Ethiopia] CSA. Ethiopia Demographic and Health Survey (EDHS); 2000. Central Statistical Agency [Ethiopia] 2000.

15. De Onis M, Dewey KG, Borghi E, Onyango AW, Blössner M, Daelmans B, et al. The World Health Organization's global target for reducing childhood stunting by 2025: rationale and proposed actions. 2013;9:6-26.

16. Medhin G, Hanlon C, Dewey M, Alem A, Tesfaye F, Worku B, et al. Prevalence and predictors of undernutrition among infants aged six and twelve months in Butajira, Ethiopia: the P-MaMiE Birth Cohort. BMC public health. 2010;10(1):27.

17. office Zh. south Gondar zone population statistics. 2018.

18. Yalew B, Amsalu F, Bikes DJJNDT. Prevalence and factors associated with stunting, underweight, and wasting: A community-based cross-sectional study among children age 6-59 months at Lalibela Town, Northern Ethiopia. 2014;4(147):2161-0509.1000147.

19. Gebru TT, Tesfamichael YA, Bitow MT, Assefa NE, Abady GG, Mengesha MB, et al. Stunting and associated factors among under-five children in Wukro town, Tigray region, Ethiopia: a crosssectional study. BMC research notes. 2019;12(1):504.

20. Bogale B, Gutema BT, Chisha Y. Prevalence of Stunting and Its Associated Factors among Children of 6-59 Months in Arba Minch Health and Demographic Surveillance Site (HDSS), Southern Ethiopia: A Community-Based Cross-Sectional Study. Journal of Environmental and Public Health. 2020;2020.

21. Gebre A, Reddy PS, Mulugeta A, Sedik Y, Kahssay M. Prevalence of malnutrition and associated factors among under-five children in pastoral communities of the afar regional state, Northeast Ethiopia: a community-based cross-sectional study. Journal of nutrition and metabolism. 2019;2019.

22. Mengesha DK, Merkeb Y. Prevalence of malnutrition and associated risk factors among under-five children in Amhara Region, Ethiopia: evidence from 2016 Ethiopian Demographic and Health Survey. 2020.

23. Asfaw M, Wondaferash M, Taha M, Dube LJBPh. Prevalence of undernutrition and associated factors among children aged between six to fifty-nine months in Bule Hora district, South Ethiopia. 2015;15(1):41.

24. Amare D, Negesse A, Tsegaye B, Assefa B, Ayenie B. Prevalence of undernutrition and its associated factors among children below five years of age in Bure Town, West Gojjam Zone, Amhara National 
Regional State, Northwest Ethiopia. Advances in Public Health. 2016;2016.

25. Girma A, Woldie H, Mekonnen FA, Gonete KA, Sisay M. Undernutrition and associated factors among urban children aged 24-59 months in Northwest Ethiopia: a community-based cross-sectional study. BMC pediatrics. 2019;19(1):214.

26. Dake SK, Solomon FB, Bobe TM, Tekle HA, Tufa EG. Predictors of stunting among children 6-59 months of age in Sodo Zuria District, South Ethiopia: a community based cross-sectional study. BMC nutrition. 2019;5(1):23.

27. Kasaye HK, Bobo FT, Yilma MT, Woldie M. Poor nutrition for under-five children from poor households in Ethiopia: Evidence from 2016 Demographic and Health Survey. PloS one. 2019;14(12):e0225996.

28. Haile A. Prevalence of Undernutrition and Associated Factors among Children Aged 6-59 Months in Bishoftu Town, Oromia Region, Ethiopia. Food Proc Nutr Sci. 2020;1(1):8-24.

29. Abera L, Dejene T, Laelago T. Magnitude of stunting and its determinants in children aged 6-59 months among rural residents of Damot Gale district; southern Ethiopia. BMC research notes. 2018;11(1):557.

30. Mehta NM, Corkins MR, Lyman B, Malone A, Goday PS, Carney L, et al. Defining pediatric malnutrition: a paradigm shift toward etiology-related definitions. Journal of Parenteral and Enteral Nutrition. 2013;37(4):460-81.

31. Wuneh MT, Guracho YD. Nutritional status and feeding practice of children 6-59 months old, Metekele zone of Benishangul-Gumuz region, Northwest Ethiopia. Science Journal of Clinical Medicine. 2017;6(6):120-9.

32. Mzumara B, Bwembya P, Halwiindi H, Mugode R, Banda JJBN. Factors associated with stunting among children below five years of age in Zambia: evidence from the 2014 Zambia demographic and health survey. 2018;4(1):51.

33. Ekpo UF, Omotayo AM, Dipeolu MA. Prevalence of malnutrition among settled pastoral Fulani children in Southwest Nigeria. BMC Research Notes. 2008;1(1):7.

34. Praditsorn P, Churak P, Wimonpeerapattana W, Moore T, Bovill M. Prevalence of undernutrition and associated factors among children 6 to 59 months of age in refugee camps along ThailandMyanmar border. Southeast Asian Journal of Tropical Medicine and Public Health. 2019;50(2):37282.

35. Bhutia DT. Protein-energy malnutrition in India: the plight of our under-five children. Journal of family medicine and primary care. 2014;3(1):63.

36. Hein AK, Hong SA, Puckpinyo A, Tejativaddhana P. Dietary diversity, social support, and stunting among children aged 6-59 months in an internally displaced person camp in Kayin state, Myanmar. Clinical Nutrition Research. 2019;8(4):307-17.

37. Fentahun W, Wubshet M, Tariku A. Undernutrition and associated factors among children aged 6-59 months in East Belesa District, northwest Ethiopia: a community based cross-sectional study. BMC public health. 2016;16(1):506. 
38. Bachewe FN, Yimer F, Minten B. Agricultural price evolution in drought versus non-drought affected areas in Ethiopia: An updated assessment using national producer data (January 2014 to January 2017). International Food Policy Research Institute (IFPRI), 2017.

39. Irenso AA, Dessie Y, Berhane Y, Assefa N, Canavan CR, Fawzi WW. Prevalence and predictors of adolescent linear growth and stunting across the urban-rural gradient in eastern Ethiopia. Tropical Medicine \& International Health. 2020;25(1):101-10.

40. Song Y, Agardh A, Ma J, Li L, Lei Y, Stafford RS, et al. National trends in stunting, thinness, and overweight among Chinese school-aged children, 1985-2014. International Journal of Obesity. 2019;43(2):402-11.

\section{Figures}

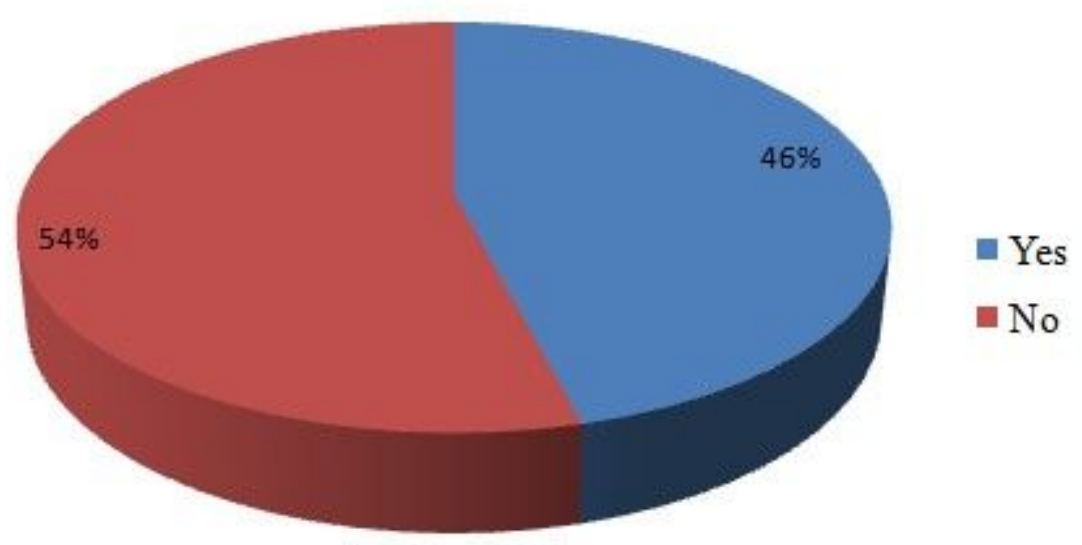

\section{Figure 1}

Prevalence of stunting among children age 6-59 months at Debre tabor town Northwest Ethiopia, $2019(n=620)$ 